In Cooperation With the Miami Conservancy District

\title{
Annual Peak-Flow and Peak Dam-Pool-Elevation Frequency Characteristics of Selected Dry Dams in the Great Miami River Basin, Ohio
}

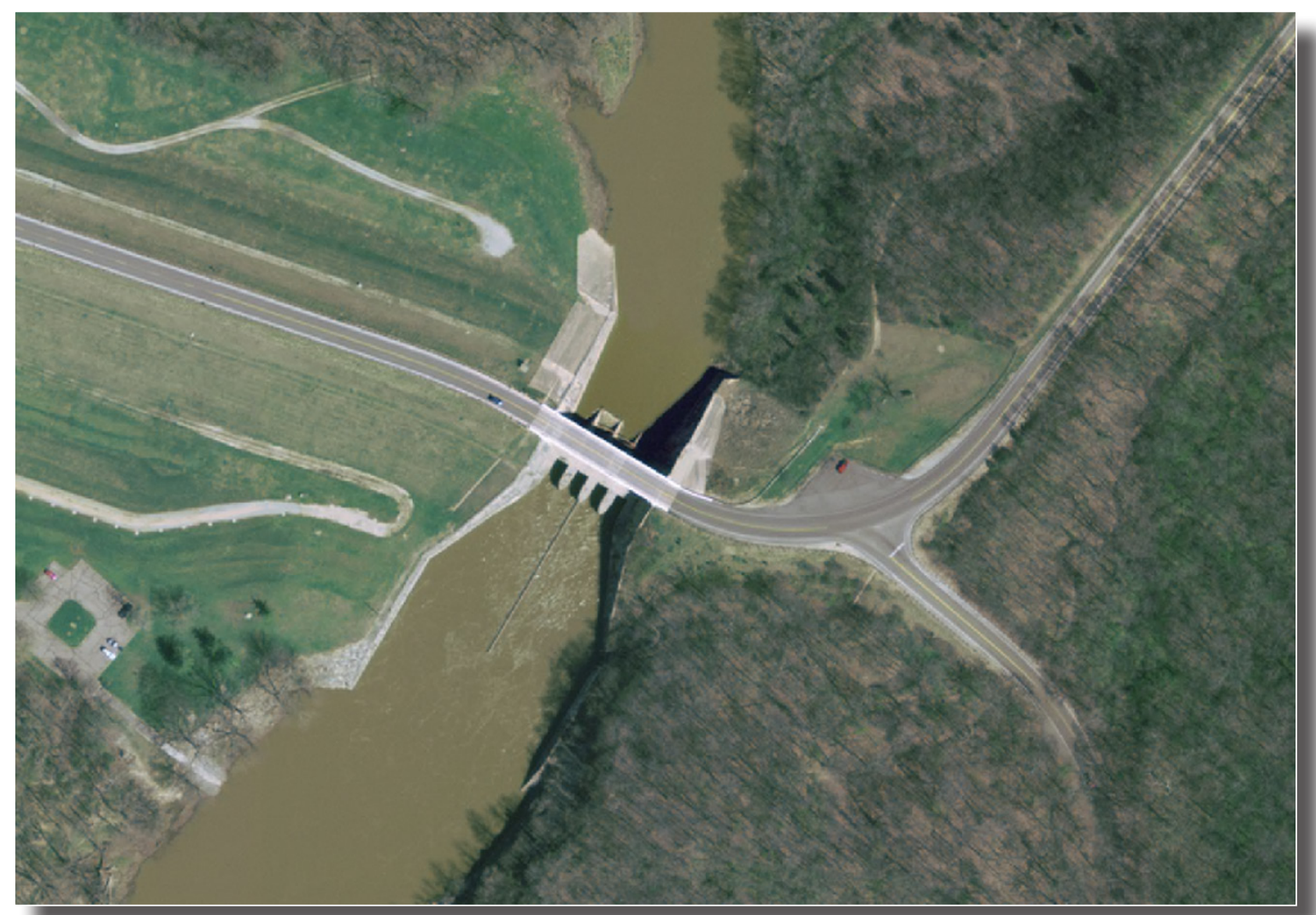

Open-File Report 2009-1069 
Cover image: Aerial view of Taylorsville Dam, Montgomery County, Ohio. (Photo from Ohio Statewide Imagery Program .) 


\section{Annual Peak-Flow and Peak Dam-Pool- Elevation Frequency Characteristics of Selected Dry Dams in the Great Miami River Basin, Ohio}

By G.F. Koltun

In cooperation with the Miami Conservancy District

Open-File Report 2009-1069 


\title{
U.S. Department of the Interior \\ KEN SALAZAR, Secretary
}

\author{
U.S. Geological Survey \\ Suzette M. Kimball, Acting Director
}

\section{U.S. Geological Survey, Reston, Virginia: 2009}

\begin{abstract}
For more information on the USGS - the Federal source for science about the Earth, its natural and living resources, natural hazards, and the environment, visit http://www.usgs.gov or call 1-888-ASK-USGS

For an overview of USGS information products, including maps, imagery, and publications, visit http://www.usgs.gov/pubprod

To order this and other USGS information products, visit http://store.usgs.gov
\end{abstract}

Any use of trade, product, or firm names is for descriptive purposes only and does not imply endorsement by the U.S. Government.

Although this report is in the public domain, permission must be secured from the individual copyright owners to reproduce any copyrighted materials contained within this report.

Suggested citation:

Koltun, G.F., 2009, Annual peak-flow and peak dam-pool-elevation frequency characteristics of selected dry dams in the Great Miami River Basin, Ohio: U.S. Geological Survey Open-File Report 2009-1069, 13 p. 


\section{Contents}

Abstract
Introduction.
Description of the Study Area
Purpose and Scope
Data Aggregation and Quality Assurance Checks
Determination of Peak Dam-Pool Storages
Tests for Trends
Frequency Analyses
Analysis of Peak Flows
Analysis of Annual Peak Dam-Pool Elevations
References Cited.
Appendix 1. Annual Peak-Flow and Peak-Storage Data

\section{Figures}

1. Locations of selected streamflow-gaging stations and dry dams in the Great Miami River Basin, Ohio

2. Scatterplot of annual peak flows against non-zero annual peak storages for the Taylorsville, Huffman, and Germantown Dams, Ohio, water years 1922-2007. .5

3. Plot of elevation against dam-pool storage for the Taylorsville, Huffman, and Germantown Dams, Ohio

\section{Tables}

1. Peak-flow frequency estimates at streamflow-gaging stations below three dry dams in the Great Miami River Basin, Ohio

2. Peak dam-pool-elevation frequency characteristics for three dry dams in the Great Miami River Basin, Ohio

1-1. Annual peak streamflows for streamflow-gaging stations 03263000,03270000 , and 03272000 , water years 1921-2007.

1-2. Annual peak dam-pool storages for the Taylorsville, Huffman, and Germantown Dams, water years 1922-2008 


\section{Conversion Factors and Datums}

\begin{tabular}{lcl}
\hline \multicolumn{1}{c}{ Multiply } & By & \multicolumn{1}{c}{ To obtain } \\
\hline foot $(\mathrm{ft})$ & Length & meter $(\mathrm{m})$ \\
mile (mi) & 0.3048 & kilometer $(\mathrm{km})$ \\
\hline & 1.609 & \\
\hline acre & Area & square meter $\left(\mathrm{m}^{2}\right)$ \\
acre & 4,047 & square kilometer $\left(\mathrm{km}^{2}\right)$ \\
square mile $\left(\mathrm{mi}^{2}\right)$ & 0.004047 & square kilometer $\left(\mathrm{km}^{2}\right)$ \\
\hline & 2.590 & \\
\hline cubic foot $\left(\mathrm{ft}^{3}\right)$ & Volume & cubic meter $\left(\mathrm{m}^{3}\right)$ \\
acre-foot $($ acre-ft) & 0.02832 & cubic meter $\left(\mathrm{m}^{3}\right)$ \\
\hline & 1,233 & \\
\hline cubic foot per second $\left(\mathrm{ft}^{3} / \mathrm{s}\right)$ & Flow rate & cubic meter per second \\
& 0.02832 & $\left(\mathrm{~m}^{3} / \mathrm{s}\right)$ \\
cubic foot per second $\mathrm{per}$ & & cubic meter per second per \\
square mile $\left[\left(\mathrm{ft}^{3} / \mathrm{s}\right) / \mathrm{mi}^{2}\right]$ & 0.01093 & square $\mathrm{kilometer}^{2}$ \\
& & {$\left[\left(\mathrm{~m}^{3} / \mathrm{s}\right) / \mathrm{km}^{2}\right]$} \\
\hline
\end{tabular}

Vertical coordinate information is referenced to the U.S. Army Corps of Engineers datum of 1912 (COE 1912).

Horizontal coordinate information is referenced North American Datum of 1983 (NAD 83).

Elevation, as used in this report, refers to distance above the vertical datum. 


\title{
Annual Peak-Flow and Peak Dam-Pool-Elevation Frequency Characteristics of Selected Dry Dams in the Great Miami River Basin, Ohio
}

\author{
By G. F. Koltun
}

\section{Abstract}

This report describes the results of a study to determine frequency characteristics of post-regulation annual peak flows at streamflow-gaging stations near the Taylorsville, Huffman, and Germantown dry dams in the Miami Conservancy District flood-protection system (southwestern Ohio), and of annual peak elevations of the corresponding dam pools. Log-Pearson Type III distributions were fit to annual peak flow values for the period 1921 or 1922 through 2007 (the most recent year of published peak flow values at the time of this analysis) and annual peak dam-pool storage values for the period 1922 2008 to determine peaks with recurrence intervals of 2, 5, $10,25,50,100,200$, and 500 years. Once storages had been estimated for the various recurrence intervals, corresponding dam-pool elevations were determined from elevation-storage ratings provided by the Miami Conservancy District.

\section{Introduction}

The Miami Conservancy District (MCD), whose jurisdiction lies within the Great Miami River basin in southwestern Ohio (fig. 1), is responsible for the operation and maintenance of a flood-protection system that includes five gateless dry dams: Germantown, Englewood, Lockington, Taylorsville, and Huffman. These dams were designed to safely pass the Official Plan Flood (OPF), which is equal to the 1913 flood magnitude plus 40 percent additional flow (Miami Conservancy District, 2009). Flow through the dams is controlled by means of conduits designed to pass only the amount of water that can be conveyed within the banks of the downstream channel. Excess floodwaters are stored behind the dams in temporary pools, which gradually drain as inflow rates to the dam pools fall below the outflow rates. During times of low to moderate flow, water flows in the conduits through the dams unimpeded, leaving no permanent pools (hence the name "dry dams").

The dams were constructed simultaneously between 1918 and 1922. Streamflow-gaging stations have been operated near the outlets of each of the dams for all or most of the period since the dams were constructed. In addition, the MCD has collected and maintained records of annual peak dam-pool elevations as well as peak dam-pool elevations associated with selected smaller floods that resulted in water storage in the dam pools. Frequency characteristics of the peak flows discharged through the dams and of annual peak dam-pool elevations have been assessed in the past (Webber and Bartlett, 1977; Song, 1979); however, those assessments were based on appreciably less data than are currently available (2009).

Accurate information on peak flow and annual peak dampool-elevation frequency characteristics is important to regulators and emergency managers so that they can make informed decisions about flood-related risks. Consequently, there is a periodic need to reevaluate those characteristics to improve the accuracy of frequency estimates and to evaluate and reflect any changes in frequency characteristics that may result from changes in hydrology. To help meet that need, the U.S. Geological Survey (USGS), in cooperation with the Miami Conservancy District, did a study to characterize annual peak flows and peak dam-pool-elevation frequency characteristics of three of the dry dams in the Great Miami River basin, Ohio

\section{Description of the Study Area}

The part of the Great Miami River Basin within the jurisdictional boundaries of the MCD drains approximately $3,900 \mathrm{mi}^{2}$ in southwestern Ohio and small parts of Indiana. The MCD's jurisdictional boundary encompasses all of the Great Miami River drainage except that from the Whitewater River, which itself drains approximately $1,470 \mathrm{mi}^{2}$ (mostly from Indiana) and discharges to the Great Miami River about $6.3 \mathrm{mi}$ upstream from its mouth. The Great Miami River Basin within the jurisdictional boundaries of the MCD will be referred to simply as "the basin" for the remainder of this report.

The basin lies almost entirely within the Till Plains section of the Central Lowlands physiographic province (Fenneman, 1938). Most of the basin was glaciated, resulting in flat to gently rolling land surfaces that are cut by steepwalled river valleys of low to moderate relief (DeBrewer and others, 2000). Glacial till overlies most of the basin; however, coarse-grained stratified sediments consisting of well-sorted sand and gravel also are common, particularly in river valleys.

The basin has a temperate continental climate characterized by well-defined winter and summer seasons that are accompanied by large annual temperature variations (Debrewer and others, 2000). On average, about 38.3 in. of precipitation falls annually within the basin, on the basis of data collected from 1915 through 2000 (Miami Conservancy 


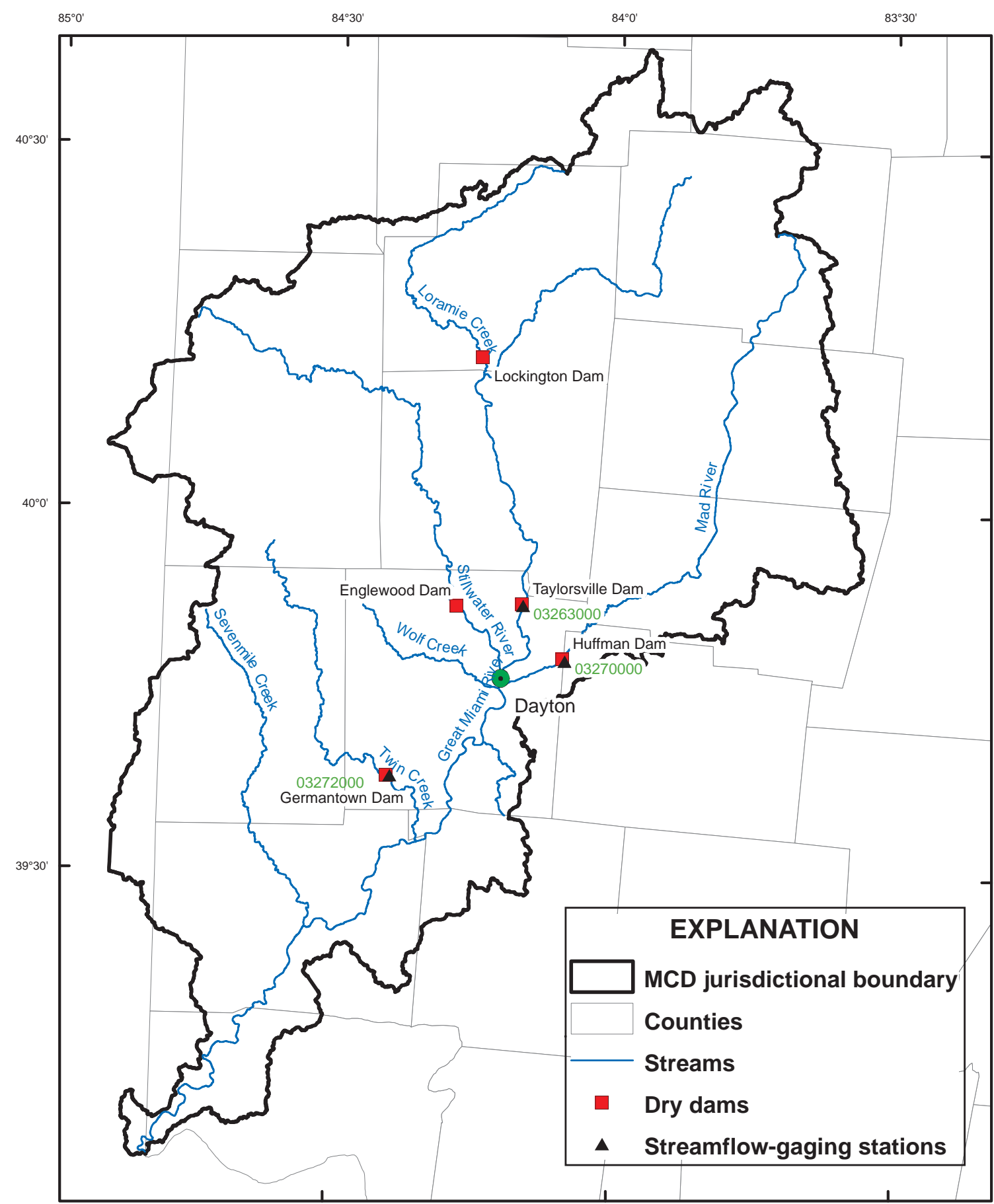

Base from U.S. Geological Survey digital data, variously scaled Projection is State Plane Ohio South
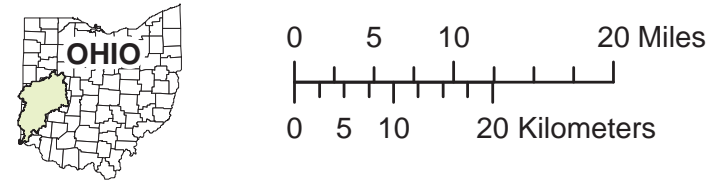

Figure 1. Locations of selected streamflow-gaging stations and dry dams in the Great Miami River Basin, Ohio. 
District, 2007), with an average runoff of about 12.6 in. March through August tend to be the wettest months; January and February tend to be the driest (Debrewer and others, 2000).

The Taylorsville, Huffman, and Germantown dams discussed in this report are on the Great Miami River, Mad River, and Twin Creek, respectively. The drainage area upstream from the Taylorsville dam (at Taylorsville, Ohio) is the largest for the three dams at 1,149 $\mathrm{mi}^{2}$. The drainage area upstream from Huffman dam (near Dayton, Ohio) is the second largest $\left(635 \mathrm{mi}^{2}\right)$ and the drainage area upstream from Germantown dam (near Germantown, Ohio) is the smallest $\left(275 \mathrm{mi}^{2}\right)$. A description of these and the other two dry dams in the MCD flood-protection system can be found at http://www. miamiconservancy.org/flood/dams.asp.

\section{Purpose and Scope}

The purpose of this report is to describe the results of a study to determine selected frequency characteristics of post-regulation annual peak flows measured at streamflowgaging stations near the outlets of three of the five dry dams in the MCD flood-protection system (Taylorsville, Huffman, and Germantown) and to determine frequency characteristics of annual peak elevations in their corresponding dam pools. Because of the close proximity of the gaging stations to the dams, peak flows at the gaging stations are considered to be approximately equal to peak flows discharging through the dams. Frequency characteristics presented in this report are based on annual peak streamflows from water years 1921 or 1922 through 2007 and annual peak dam-pool elevations from water years ${ }^{1} 1922$ through 2008.

\section{Data Aggregation and Quality- Assurance Checks}

Annual peak flow values and the dates of their occurrence (Appendix 1, table 1-1) were retrieved from the USGS National Water Information System (NWIS) for USGS streamflow-gaging stations 03263000 (Great Miami River at Taylorsville, Ohio), 03270000 (Mad River near Dayton, Ohio), and 03272000 (Twin Creek near Germantown, Ohio). A suite of tests (Ryberg, 2008) were run on the annual peak flow data as quality-assurance checks. All potential data-quality issues identified in the tests were examined further to ensure that the peak flow data were accurate.

Annual peak dam-pool elevations and the dates of their occurrences were provided by the MCD. In most cases, these annual peak dam-pool elevations were determined from staff-gage readings made at the dams by MCD personnel. In some cases, the elevations were determined by means of automated equipment that measures and records the height of water above a reference datum.

\footnotetext{
${ }^{1}$ A water year is the period from October 1 to September 30 and is designated by the calendar year in which it ends.
}

As a quality-assurance check, annual peak dam-pool-elevation data were paired by date of occurrence with corresponding peak-flow values (when available) retrieved from NWIS. ${ }^{2}$ Outflow ratings, developed by digitizing outlet-capacity rating curves contained in a MCD report (Miami Conservancy District, 1964), were used to estimate peak flows as a function of peak dam-pool elevations. The estimated peak flows were compared with peak-flow values retrieved from the NWIS database to ensure that there were no substantial discrepancies.

\section{Determination of Peak Dam-Pool Storages}

As discussed in more detail later, annual peak storages in the dam pools were used to determine frequency characteristics of peak dam-pool elevations. Elevation-storage ratings for the dam pools were provided to the USGS by the MCD. The MCD used a geographic information system to determine elevation-storage ratings for the dam pools on the basis of a 2.5 -ft grid digital elevation model that was developed by the Ohio Statewide Imagery Program (a partnership between State agencies and the Federal government). Storages determined for elevations ranging from the conduit inverts to at or near the top of the dams (in 0.1-ft increments) were used in look-up form to determine the storages associated with the annual peak dam-pool elevations (Appendix 1, table 1-2).

\section{Tests for Trends}

The annual peak flow and peak dam-pool storage time series were tested for stationarity by means of the Kendall test for trends, as implemented in the USGS program SWSTAT (U.S. Geological Survey, 2009). The Kendall test for trends involves calculating a nonparametric measure of correlation (tau) between time and corresponding measures of some characteristic (in this case, annual peak flows or peak dampool storages). None of the time series exhibited statistically significant trends at $\alpha=0.05$, thereby supporting the assumption of stationarity that is required for frequency analysis.

\section{Frequency Analyses}

Frequency analyses were done to estimate peak-flow and peak dam-pool-elevation magnitudes with recurrence intervals of $2,5,10,25,50,100,200$, and 500 years (annual exceedance probabilities of $0.5,0.2,0.1,0.04,0.02,0.01,0.005$, and 0.002 , respectively). Methods used to compute these frequency characteristics are described below.

\footnotetext{
${ }^{2}$ The dates of peak streamflow and peak dam-pool storage for a given water year are not the same in all cases. There are a variety of reasons (for example, obstructions lodging in outflow conduits) that can cause this to occur.
} 


\section{Analysis of Peak Flows}

Peak-flow frequency estimates were determined by fitting a log-Pearson Type III distribution to the base-10 logarithms of the annual peak-flow series. The peak flows corresponding to selected recurrence intervals were computed by the following equation:

where

$$
\log _{10}\left(Q_{t}\right)=\bar{X}+K(S)
$$

$Q_{t} \quad$ is the t-year-recurrence-interval peak flow, in cubic feet per second,

$\bar{X} \quad$ is the mean of the logarithms of the annual peak flows,

$K \quad$ is a factor dependent on the recurrence interval and the skew coefficient of the log-transformed annual peak flow series, and

$S \quad$ is the standard deviation of the logtransformed annual peak-flow series.

Peak-flow frequency estimates were calculated with version 5.2 of the USGS program PKFQWin (U.S. Geological Survey, 2009), which is a Windows Operating System version of the USGS program PEAKFQ (Flynn and others, 2006). PKFQWin performs frequency analyses on the basis of guidelines established by the Interagency Advisory Committee on Water Data (1982). Station skew was used instead of the weighted skew in all cases because skews may be affected by regulation from the dry dams and therefore may be inconsistent with regional skew estimates. Peak-flow frequency estimates determined for stations 03263000, 03270000, and 03272000 are reported in table 1.

\section{Analysis of Annual Peak Dam-Pool Elevations}

Frequency characteristics of peak dam-pool elevations were not determined from direct analysis of the annual peak dam-pool-elevation time series but instead were determined from corresponding annual peak dam-pool storages. Annual peak storage in the dam pool generally is closely related to annual peak streamflow at dry dams (fig. 2). The same cannot necessarily be said about the relation between peak flows and peak dam-pool elevations because elevation-storage relations vary as a function of water level at a given dam due to variable topography of the dam pools (fig. 3). An added benefit of analyzing storages instead of elevations is that the strong linear correlation between logarithms of annual peak flows and annual peak storages at dry dams gives theoretical support that a log-Pearson Type III distribution can be used to describe the storage-frequency characteristics.

Annual peak dam-pool-elevation frequency characteristics were estimated with version 5.2 of the USGS program PKFQWin (U.S. Geological Survey, 2009) by determining the parameters of a log-Pearson Type III distribution that fit the base-10 logarithms of the observed annual peak dam-pool
Table 1. Peak-flow frequency estimates at streamflow-gaging stations below three dry dams in the Great Miami River Basin, Ohio.

$\left[\mathrm{ft}^{3} / \mathrm{s}\right.$, cubic feet per second]

\begin{tabular}{|c|c|c|c|c|}
\hline \multirow{2}{*}{$\begin{array}{c}\text { Annual } \\
\text { exceedance } \\
\text { probability }\end{array}$} & \multirow{2}{*}{$\begin{array}{l}\text { Recur- } \\
\text { rence } \\
\text { interval } \\
\text { (years) }\end{array}$} & \multirow{2}{*}{$\begin{array}{c}\text { Peak } \\
\text { stream- } \\
\text { flow }\left(\mathrm{ft}^{3} / \mathrm{s}\right)\end{array}$} & \multicolumn{2}{|c|}{$\begin{array}{l}\text { 95-percent confidence } \\
\text { limits }\end{array}$} \\
\hline & & & $\begin{array}{c}\text { Lower } \\
\left(\mathrm{ft}^{3} / \mathrm{s}\right)\end{array}$ & $\begin{array}{l}\text { Upper } \\
\left(\mathrm{ft}^{3} / \mathrm{s}\right)\end{array}$ \\
\hline \multicolumn{5}{|c|}{ Great Miami River at Taylorsville, Ohio (03263000) } \\
\hline 0.500 & 2 & 15,000 & 14,000 & 16,100 \\
\hline 0.200 & 5 & 20,100 & 18,600 & 21,900 \\
\hline 0.100 & 10 & 22,800 & 20,900 & 25,200 \\
\hline 0.040 & 25 & 25,700 & 23,400 & 28,800 \\
\hline 0.020 & 50 & 27,500 & 24,900 & 31,000 \\
\hline 0.010 & 100 & 29,000 & 26,200 & 33,000 \\
\hline 0.005 & 200 & 30,400 & 27,300 & 34,700 \\
\hline 0.002 & 500 & 32,000 & 28,600 & 36,700 \\
\hline \multicolumn{5}{|c|}{ Mad River near Dayton, Ohio (03270000) } \\
\hline 0.500 & 2 & 7,200 & 6,670 & 7,770 \\
\hline 0.200 & 5 & 10,300 & 9,510 & 11,360 \\
\hline 0.100 & 10 & 12,500 & 11,400 & 14,000 \\
\hline 0.040 & 25 & 15,400 & 13,800 & 17,600 \\
\hline 0.020 & 50 & 17,600 & 15,600 & 20,500 \\
\hline 0.010 & 100 & 19,900 & 17,400 & 23,500 \\
\hline 0.005 & 200 & 22,300 & 19,300 & 26,700 \\
\hline 0.002 & 500 & 25,500 & 21,800 & 31,100 \\
\hline \multicolumn{5}{|c|}{ Twin Creek near Germantown, Ohio (03272000) } \\
\hline 0.500 & 2 & 6,120 & 5,840 & 6,420 \\
\hline 0.200 & 5 & 7,240 & 6,880 & 7,670 \\
\hline 0.100 & 10 & 7,700 & 7,290 & 8,210 \\
\hline 0.040 & 25 & 8,100 & 7,640 & 8,680 \\
\hline 0.020 & 50 & 8,300 & 7,820 & 8,920 \\
\hline 0.010 & 100 & 8,450 & 7,950 & 9,100 \\
\hline 0.005 & 200 & 8,570 & 8,050 & 9,240 \\
\hline 0.002 & 500 & 8,670 & 8,140 & 9,360 \\
\hline
\end{tabular}

storages. The log-Pearson Type III distribution was then used to estimated the peak dam-pool storages (and corresponding confidence limits) with recurrence intervals of 2, 5, 10, 25, 50, 100, 200, and 500 years. As described in Bulletin 17B (Interagency Advisory Committee on Water Data, 1982), conditional probability adjustments were made to the frequency estimates to account for zero-storage years (years in which peak flows were insufficient to cause water to go into dam-pool storage). Once storages had been estimated for the various recurrence intervals, corresponding dam-pool elevations were determined from the elevation-storage ratings discussed earlier. The resulting dampool-elevation frequency characteristics for the Taylorsville, Huffman, and Germantown Dams are listed in table 2. 


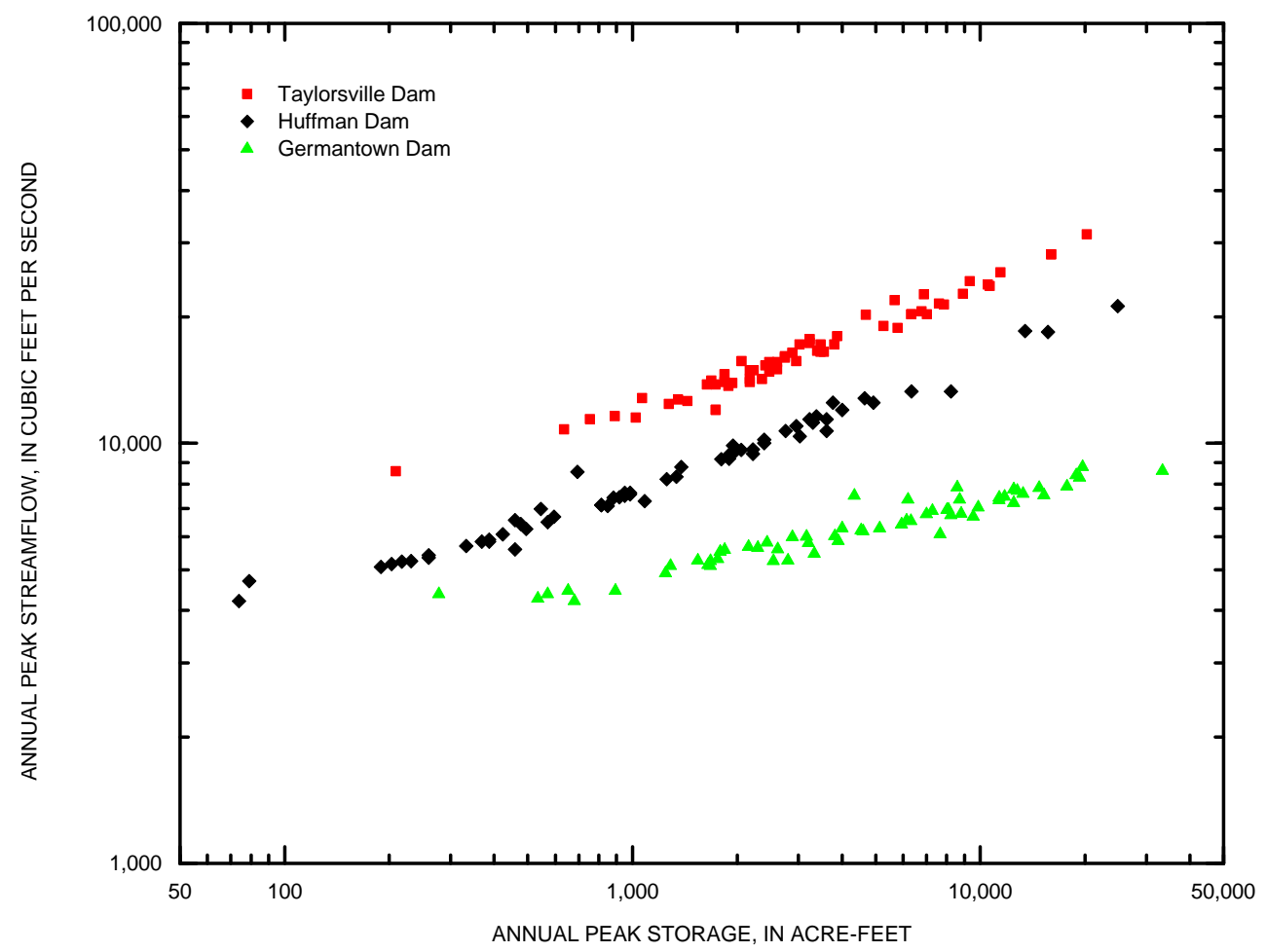

Figure 2. Scatterplot of annual peak flows against non-zero annual peak storages for the Taylorsville, Huffman, and Germantown Dams, Ohio, water years 1922-2007.

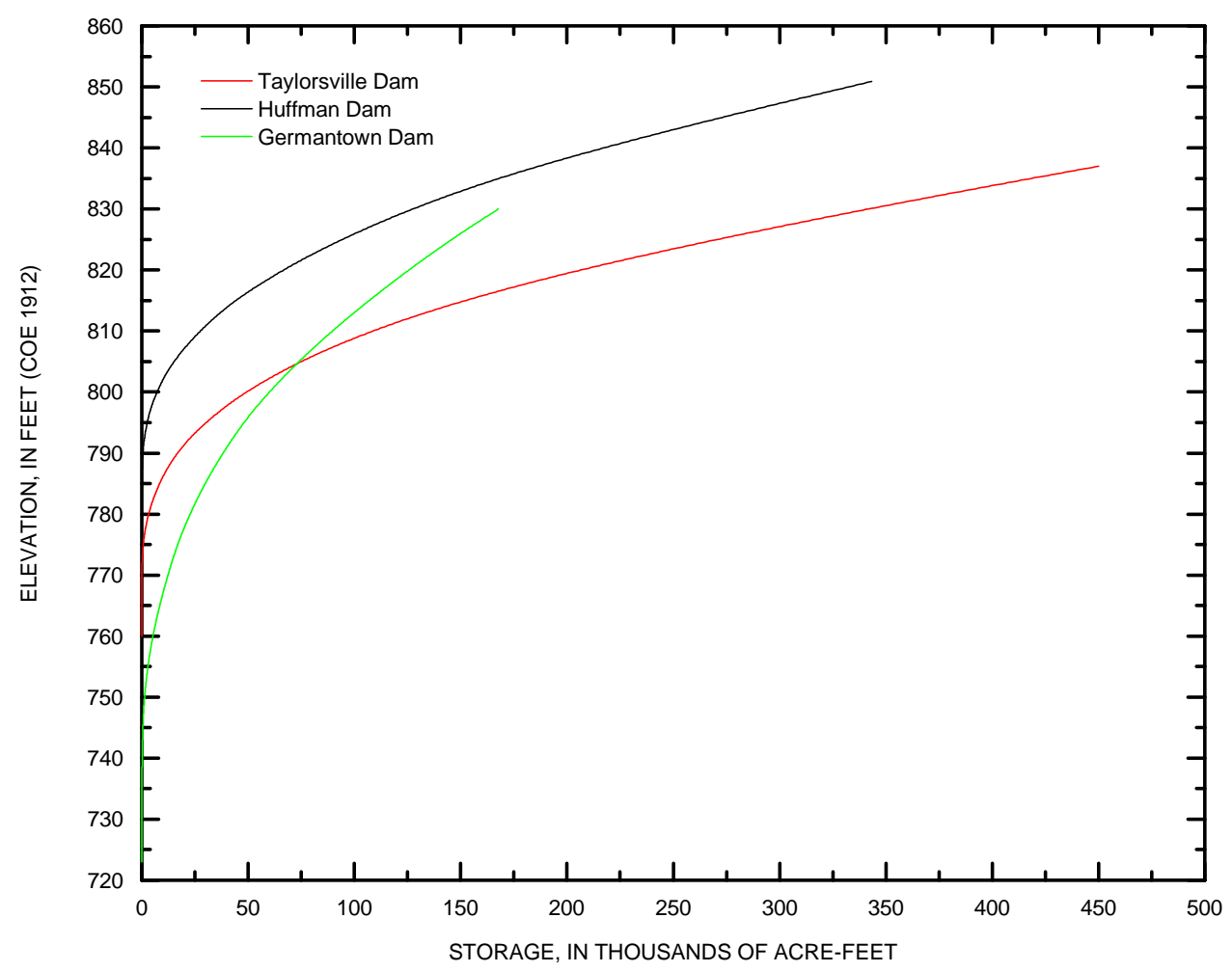

Figure 3. Plot of elevation against dam-pool storage for the Taylorsville, Huffman, and Germantown Dams, Ohio. 
Table 2. Peak dam-pool-elevation frequency characteristics for three dry dams in the Great Miami River Basin, Ohio.

[Spillway and top-of-dam elevations are referenced to the U.S. Army Corps of Engineers 1912 datum]

\begin{tabular}{|c|c|c|c|c|}
\hline \multirow{2}{*}{$\begin{array}{c}\text { Annual } \\
\text { exceedance } \\
\text { probability }\end{array}$} & \multirow{2}{*}{$\begin{array}{l}\text { Recur- } \\
\text { rence } \\
\text { interval } \\
\text { (years) }\end{array}$} & \multirow{2}{*}{$\begin{array}{c}\text { Peak } \\
\text { dam-pool } \\
\text { elevation } \\
\text { (feet) }\end{array}$} & \multicolumn{2}{|c|}{$\begin{array}{c}\text { 95-percent confidence } \\
\text { limits }\end{array}$} \\
\hline & & & $\begin{array}{c}\text { Lower } \\
\text { (feet) }\end{array}$ & $\begin{array}{l}\text { Upper } \\
\text { (feet) }\end{array}$ \\
\hline \multicolumn{5}{|c|}{ Taylorsville Dam (spillway, 818 feet; top of dam, 837 feet) } \\
\hline 0.5000 & 2.00 & 778.8 & 778.1 & 779.4 \\
\hline 0.2000 & 5.00 & 782.3 & 781.4 & 783.5 \\
\hline 0.1000 & 10.00 & 784.7 & 783.5 & 786.3 \\
\hline 0.0400 & 25.00 & 787.7 & 786.0 & 790.0 \\
\hline 0.0200 & 50.00 & 789.9 & 787.8 & 792.6 \\
\hline 0.0100 & 100.00 & 792.0 & 789.6 & 795.1 \\
\hline 0.0050 & 200.00 & 794.0 & 791.3 & 797.7 \\
\hline 0.0020 & 500.00 & 796.7 & 793.5 & 801.2 \\
\hline \multicolumn{5}{|c|}{ Huffman Dam (spillway, 835 feet; top of dam, 850 feet) } \\
\hline 0.5000 & 2.00 & 791.0 & 790.3 & 791.7 \\
\hline 0.2000 & 5.00 & 794.9 & 793.8 & 796.3 \\
\hline 0.1000 & 10.00 & 797.8 & 796.2 & 799.7 \\
\hline 0.0400 & 25.00 & 801.4 & 799.2 & 804.5 \\
\hline 0.0200 & 50.00 & 804.2 & 801.4 & 808.1 \\
\hline 0.0100 & 100.00 & 807.0 & 803.7 & 812.1 \\
\hline 0.0050 & 200.00 & 810.0 & 805.9 & 816.3 \\
\hline 0.0020 & 500.00 & 814.2 & 809.0 & 822.2 \\
\hline \multicolumn{5}{|c|}{ Germantown Dam (spillway, 815 feet; top of dam, 830 feet) } \\
\hline 0.5000 & 2.00 & 757.3 & 755.6 & 759.0 \\
\hline 0.2000 & 5.00 & 766.2 & 763.6 & 769.7 \\
\hline 0.1000 & 10.00 & 772.1 & 768.4 & 776.9 \\
\hline 0.0400 & 25.00 & 778.9 & 774.2 & 785.0 \\
\hline 0.0200 & 50.00 & 783.3 & 778.0 & 790.5 \\
\hline 0.0100 & 100.00 & 787.3 & 781.3 & 795.6 \\
\hline 0.0050 & 200.00 & 791.0 & 784.3 & 800.2 \\
\hline 0.0020 & 500.00 & 795.5 & 788.0 & 805.7 \\
\hline
\end{tabular}

\section{Summary}

This report describes the results of a study, done in cooperation with the Miami Conservancy District, to determine frequency characteristics of post-regulation annual peak flows at streamflow-gaging stations near three dry dams (Taylorsville, Huffman, and Germantown) in the MCD flood-protection system and annual peak elevations of the corresponding dam pools. These frequency characteristics are used by regulators and emergency managers to make informed decisions about flood-related risks.
Annual peak-flow time series obtained from the USGS NWIS database and annual peak dam-pool elevation time series provided by the MCD were checked to ensure accuracy, consistency, and stationarity. Log-Pearson Type III distributions were fit to annual peak flow values and annual peak dam-pool storage values to determine peaks with recurrence intervals of 2, 5, 10, 25, 50, 100, 200, and 500 years. Conditional probability adjustments were made to the dam-pool storage frequency estimates to account for zero-storage years. Once storages had been estimated for the various recurrence intervals, corresponding dam-pool elevations were determined from elevation-storage ratings provided by the MCD.

\section{References Cited}

Debrewer, L.M., Rowe, G.L., Reutter, D.C., Moore, R.C., Hambrook, J.A., and Baker, N.T., 2000, Environmental setting and effects on water quality in the Great and Little Miami River Basins, Ohio and Indiana: U.S. Geological Survey WaterResources Investigation Report 99-4201, 98 p.

Fenneman, N.M., 1938, Physiography of eastern United States: New York, McGraw-Hill, 691 p.

Flynn, K.M., Kirby, W.H., and Hummel, P.R., 2006, User's manual for program PeakFQ, annual flood frequency analysis using Bulletin 17B Guidelines: U.S. Geological Survey Techniques and Methods book 4, chap. B4, $42 \mathrm{p}$.

Interagency Advisory Committee on Water Data, 1982, Guidelines for determining flood flow frequency - Bul $\neg$ letin 17-B of the Hydrology Subcommittee: Reston, Va., U.S. Geological Survey, Office of Water Data Coordination, $183 \mathrm{p}$.

Miami Conservancy District, 1964, Restudy of the Official Plan Part 1 -Development and verification of a flood routing model of the Miami River Basin: Dayton, Ohio, Report 64-8, 108 p.

Miami Conservancy District, 2007, Miami Conservancy District-2007 annual report: Dayton, Ohio, 92 p.

Miami Conservancy District, 2009, Flood protection-Official Plan Flood, accessed on March 13, 2009, at http://www. miamiconservancy.org/flood/plan.asp

Ryberg, K.R., 2008, PFReports-A program for systematic checking of annual peaks in NWISWeb: U.S. Geological Survey Open-File Report 2008-1284, 17 p.

Song, Lawrence, 1979, Flood frequencies in the Great Miami River Basin: Dayton, Ohio, Miami Conservancy District Report 79-1 [variously paginated].

U.S. Geological Survey, 2009, SWSTAT-Surface-water statistics, accessed on March 27, 2009, at http://water.usgs. gov/software/SWSTAT/

Webber, E.E., and Bartlett, W.P., Jr., 1977, Floods in Ohiomagnitude and frequency: Ohio Department of Natural Resources Division of Water Bulletin 45, 74 p. 


\section{Appendix 1. Annual Peak-Flow and Peak-Storage Data}


Table 1-1. Annual peak streamflows for streamflow-gaging stations 03263000, 03270000, and 03272000, water years 1921-2007.

[ft $3 / \mathrm{s}$, cubic feet per second; nop, station not in operation; pre, preregulation]

\begin{tabular}{|c|c|c|c|c|c|c|}
\hline \multirow{2}{*}{ Water year } & \multicolumn{2}{|c|}{$\begin{array}{l}\text { Great Miami River at } \\
\text { Taylorsville (03263000) }\end{array}$} & \multicolumn{2}{|c|}{$\begin{array}{l}\text { Mad River near Dayton } \\
(03270000)\end{array}$} & \multicolumn{2}{|c|}{$\begin{array}{l}\text { Twin Creek near Germantown } \\
(03272000)\end{array}$} \\
\hline & Date & $\begin{array}{l}\text { Peak flow } \\
\left(\mathrm{ft}^{3} / \mathrm{s}\right)\end{array}$ & Date & $\begin{array}{l}\text { Peak flow } \\
\left(\mathrm{ft}^{3} / \mathrm{s}\right)\end{array}$ & Date & $\begin{array}{l}\text { Peak flow } \\
\left(\mathrm{ft}^{3} / \mathrm{s}\right)\end{array}$ \\
\hline 1921 & nop & nop & pre & pre & 03/29/1921 & 5,630 \\
\hline 1922 & 04/15/1922 & 17,300 & 04/15/1922 & 10,000 & 04/15/1922 & 6,070 \\
\hline 1923 & 05/16/1923 & 10,600 & 03/16/1923 & 5,590 & 03/16/1923 & 4,270 \\
\hline 1924 & 06/09/1924 & 21,600 & 03/29/1924 & 12,500 & nop & nop \\
\hline 1925 & 04/22/1925 & 5,610 & 04/22/1925 & 6,060 & nop & nop \\
\hline 1926 & 04/09/1926 & 13,800 & 04/09/1926 & 4,120 & nop & nop \\
\hline 1927 & 03/22/1927 & 21,600 & 01/20/1927 & 9,880 & 04/05/1927 & 5,400 \\
\hline 1928 & $12 / 14 / 1927$ & 14,000 & $12 / 01 / 1927$ & 6,420 & 12/01/1927 & 6,410 \\
\hline 1929 & 02/26/1929 & 23,700 & 02/26/1929 & 18,400 & 02/27/1929 & 7,640 \\
\hline 1930 & 01/10/1930 & 20,600 & 01/09/1930 & 10,600 & 01/10/1930 & 6,800 \\
\hline 1931 & 04/04/1931 & 4,750 & 04/03/1931 & 2,450 & 04/03/1931 & 2,470 \\
\hline 1932 & 01/18/1932 & 9,430 & 01/18/1932 & 8,560 & 01/17/1932 & 5,520 \\
\hline 1933 & 05/14/1933 & 25,500 & 05/14/1933 & 12,500 & 12/31/1932 & 7,350 \\
\hline 1934 & 03/03/1934 & 5,500 & 03/03/1934 & 4,530 & 03/27/1934 & 3,370 \\
\hline 1935 & 05/04/1935 & 11,400 & 05/03/1935 & 3,850 & 05/03/1935 & 4,370 \\
\hline 1936 & 02/27/1936 & 15,600 & 02/27/1936 & 6,570 & 02/26/1936 & 4,790 \\
\hline 1937 & 01/15/1937 & 25,500 & 01/22/1937 & 15,400 & 01/15/1937 & 7,890 \\
\hline 1938 & 04/09/1938 & 16,600 & 04/07/1938 & 7,500 & 03/16/1938 & 6,150 \\
\hline 1939 & 06/19/1939 & 13,600 & 04/16/1939 & 6,620 & 04/16/1939 & 5,850 \\
\hline 1940 & 04/21/1940 & 14,600 & 04/21/1940 & 5,590 & 04/20/1940 & 5,250 \\
\hline 1941 & 06/16/1941 & 4,980 & 06/04/1941 & 1,380 & 06/11/1941 & 1,720 \\
\hline 1942 & 04/11/1942 & 12,800 & 02/07/1942 & 3,600 & 02/07/1942 & 4,460 \\
\hline 1943 & 03/20/1943 & 21,900 & 03/20/1943 & 11,200 & 03/20/1943 & 7,200 \\
\hline 1944 & $04 / 12 / 1944$ & 17,700 & 04/12/1944 & 7,620 & 04/12/1944 & 5,370 \\
\hline 1945 & 06/19/1945 & 17,200 & 03/07/1945 & 11,400 & 03/06/1945 & 6,360 \\
\hline 1946 & 02/14/1946 & 8,410 & 06/20/1946 & 4,520 & 02/14/1946 & 5,250 \\
\hline 1947 & 06/03/1947 & 20,200 & 06/03/1947 & 12,000 & 06/02/1947 & 7,040 \\
\hline 1948 & 02/14/1948 & 16,200 & 02/14/1948 & 13,300 & 02/14/1948 & 5,870 \\
\hline 1949 & 01/06/1949 & 17,200 & 01/06/1949 & 9,440 & 01/05/1949 & 7,520 \\
\hline 1950 & 01/16/1950 & 20,300 & 01/17/1950 & 9,200 & 01/16/1950 & 6,740 \\
\hline 1951 & $12 / 04 / 1950$ & 18,300 & $12 / 04 / 1950$ & 9,680 & 02/21/1951 & 6,690 \\
\hline 1952 & 01/27/1952 & 21,500 & 01/27/1952 & 13,300 & 01/27/1952 & 8,790 \\
\hline 1953 & 05/22/1953 & 9,210 & 05/23/1953 & 5,340 & 03/04/1953 & 2,610 \\
\hline 1954 & 06/17/1954 & 7,520 & 06/09/1954 & 2,750 & 04/17/1954 & 1,420 \\
\hline 1955 & 02/22/1955 & 9,000 & 03/22/1955 & 4,680 & 03/22/1955 & 3,970 \\
\hline 1956 & 02/26/1956 & 14,000 & 11/16/1955 & 6,430 & 11/17/1955 & 7,340 \\
\hline 1957 & 06/29/1957 & 17,200 & 04/05/1957 & 10,400 & 04/04/1957 & 7,860 \\
\hline 1958 & 06/14/1958 & 21,400 & 06/14/1958 & 10,700 & 06/11/1958 & 7,010 \\
\hline
\end{tabular}


Table 1-1. Annual peak streamflows for streamflow-gaging stations 03263000,03270000 , and 03272000 , water years 1921-2007.-Continued

\begin{tabular}{|c|c|c|c|c|c|c|}
\hline \multirow{2}{*}{ Water Year } & \multicolumn{2}{|c|}{$\begin{array}{c}\text { Great Miami River at Taylors- } \\
\text { ville (03263000) }\end{array}$} & \multicolumn{2}{|c|}{$\begin{array}{l}\text { Mad River near Dayton } \\
(03270000)\end{array}$} & \multicolumn{2}{|c|}{$\begin{array}{l}\text { Twin Creek near Germantown } \\
(\text { (03272000) }\end{array}$} \\
\hline & Date & $\begin{array}{c}\text { Peak Flow } \\
\left(\mathrm{ftt}^{3} / \mathrm{s}\right)\end{array}$ & Date & $\begin{array}{c}\text { Peak Flow } \\
\left(\mathrm{ft}^{3} / \mathrm{s}\right)\end{array}$ & Date & $\begin{array}{c}\text { Peak Flow } \\
\left(\mathrm{ft}^{3} / \mathrm{s}\right)\end{array}$ \\
\hline 1959 & 01/22/1959 & 31,400 & 01/22/1959 & 21,200 & 01/22/1959 & 8,590 \\
\hline 1960 & 02/11/1960 & 6,310 & 05/28/1960 & 3,490 & 02/10/1960 & 2,970 \\
\hline 1961 & 04/26/1961 & 16,100 & 04/26/1961 & 6,980 & 04/26/1961 & 6,300 \\
\hline 1962 & 02/27/1962 & 12,400 & 02/27/1962 & 7,140 & 02/26/1962 & 5,790 \\
\hline 1963 & 03/05/1963 & 24,300 & 03/05/1963 & 18,500 & 03/05/1963 & 8,400 \\
\hline 1964 & 04/21/1964 & 18,800 & 03/10/1964 & 12,800 & 03/10/1964 & 7,420 \\
\hline 1965 & 04/26/1965 & 11,500 & 04/26/1965 & 5,160 & 04/25/1965 & 4,900 \\
\hline 1966 & 02/11/1966 & 8,570 & 02/11/1966 & 4,210 & 02/11/1966 & 4,430 \\
\hline 1967 & 12/11/1966 & 12,200 & 05/07/1967 & 4,620 & 05/07/1967 & 5,980 \\
\hline 1968 & 01/31/1968 & 10,800 & 05/28/1968 & 8,790 & 05/24/1968 & 7,760 \\
\hline 1969 & 01/30/1969 & 12,700 & 08/10/1969 & 6,680 & 01/30/1969 & 6,010 \\
\hline 1970 & 04/03/1970 & 13,900 & 04/03/1970 & 9,170 & 04/02/1970 & 6,280 \\
\hline 1971 & 06/27/1971 & 13,100 & 06/26/1971 & 7,430 & 02/22/1971 & 5,260 \\
\hline 1972 & 04/08/1972 & 11,600 & 12/30/1971 & 4,720 & 04/13/1972 & 4,210 \\
\hline 1973 & 11/15/1972 & 14,100 & 06/20/1973 & 5,840 & 11/14/1972 & 5,300 \\
\hline 1974 & 01/20/1974 & 15,700 & 04/02/1974 & 5,080 & 06/23/1974 & 5,800 \\
\hline 1975 & 02/24/1975 & 22,600 & 02/24/1975 & 11,400 & 02/24/1975 & 7,460 \\
\hline 1976 & 01/27/1976 & 11,400 & 01/26/1976 & 4,700 & 01/26/1976 & 5,140 \\
\hline 1977 & 04/03/1977 & 9,420 & 04/03/1977 & 5,420 & 04/03/1977 & 5,460 \\
\hline 1978 & 03/15/1978 & 14,900 & 03/15/1978 & 6,260 & 03/15/1978 & 6,530 \\
\hline 1979 & 02/24/1979 & 14,200 & 09/15/1979 & 7,620 & 02/24/1979 & 7,500 \\
\hline 1980 & 06/03/1980 & 15,300 & 06/29/1980 & 9,640 & 11/26/1979 & 5,660 \\
\hline 1981 & 06/15/1981 & 14,900 & 06/06/1981 & 9,470 & 06/06/1981 & 4,370 \\
\hline 1982 & 02/18/1982 & 15,600 & 02/01/1982 & 10,200 & 02/01/1982 & 6,950 \\
\hline 1983 & 05/04/1983 & 10,900 & 05/02/1983 & 5,350 & 05/04/1983 & 5,590 \\
\hline 1984 & 03/17/1984 & 10,100 & 03/16/1984 & 4,300 & 04/05/1984 & 4,450 \\
\hline 1985 & 02/24/1985 & 16,400 & 02/23/1985 & 5,750 & 02/24/1985 & 5,310 \\
\hline 1986 & 12/12/1985 & 13,800 & 03/13/1986 & 6,340 & 03/13/1986 & 5,640 \\
\hline 1987 & 10/05/1986 & 18,000 & 10/05/1986 & 6,490 & 10/02/1986 & 6,270 \\
\hline 1988 & 02/02/1988 & 6,320 & 02/02/1988 & 4,480 & 02/02/1988 & 5,260 \\
\hline 1989 & 05/27/1989 & 17,200 & 05/27/1989 & 7,290 & 05/26/1989 & 7,330 \\
\hline 1990 & 02/16/1990 & 16,000 & 07/13/1990 & 7,560 & 02/16/1990 & 6,180 \\
\hline 1991 & 12/30/1990 & 25,200 & 12/31/1990 & 10,700 & 12/31/1990 & 7,590 \\
\hline 1992 & 07/14/1992 & 13,700 & 07/18/1992 & 5,700 & 07/24/1992 & 4,880 \\
\hline 1993 & 07/03/1993 & 15,000 & 07/02/1993 & 5,900 & 04/16/1993 & 5,110 \\
\hline 1994 & 11/18/1993 & 14,200 & 01/28/1994 & 7,090 & 01/28/1994 & 5,990 \\
\hline 1995 & 08/09/1995 & 23,900 & 08/09/1995 & 5,830 & 05/19/1995 & 6,000 \\
\hline 1996 & 01/19/1996 & 16,500 & 04/30/1996 & 9,380 & 04/30/1996 & 7,710 \\
\hline 1997 & 06/02/1997 & 16,500 & 06/02/1997 & 7,450 & 06/02/1997 & 6,780 \\
\hline 1998 & 01/08/1998 & 12,300 & 05/08/1998 & 8,330 & 04/16/1998 & 5,590 \\
\hline
\end{tabular}


Table 1-1. Annual peak streamflows for streamflow-gaging stations 03263000, 03270000, and 03272000, water years 1921-2007.-Continued

\begin{tabular}{ccc|c|c|c|c}
\hline \multirow{2}{*}{ Water Year } & \multicolumn{2}{c|}{$\begin{array}{c}\text { Great Miami River at Taylors- } \\
\text { ville (03263000) }\end{array}$} & \multicolumn{2}{c|}{$\begin{array}{c}\text { Mad River near Dayton } \\
\text { (03270000) }\end{array}$} & $\begin{array}{c}\text { Twin Creek near Germantown } \\
\text { (03272000) }\end{array}$ \\
\cline { 2 - 7 } & Date & $\begin{array}{c}\text { Peak Flow } \\
\left(\mathbf{f t}^{3} / \mathbf{s}\right)\end{array}$ & Date & $\begin{array}{c}\text { Peak Flow } \\
\left(\mathbf{f t}^{3} / \mathbf{s}\right)\end{array}$ & Date & $\begin{array}{c}\text { Peak Flow } \\
\left(\mathbf{f t}^{3} / \mathbf{s}\right)\end{array}$ \\
\hline 1999 & $01 / 23 / 1999$ & 15,700 & $01 / 22 / 1999$ & 5,250 & $01 / 23 / 1999$ & 6,550 \\
2000 & $04 / 08 / 2000$ & 12,600 & $04 / 08 / 2000$ & 8,210 & $04 / 08 / 2000$ & 6,210 \\
2001 & $05 / 19 / 2001$ & 9,170 & $07 / 29 / 2001$ & 5,230 & $04 / 11 / 2001$ & 5,110 \\
2002 & $12 / 18 / 2001$ & 14,800 & $12 / 18 / 2001$ & 7,140 & $12 / 18 / 2001$ & 6,910 \\
2003 & $07 / 10 / 2003$ & 22,700 & $09 / 02 / 2003$ & 6,070 & $07 / 07 / 2003$ & 5,570 \\
2004 & $01 / 05 / 2004$ & 19,000 & $01 / 05 / 2004$ & 11,000 & $01 / 05 / 2004$ & 7,830 \\
2005 & $01 / 06 / 2005$ & 28,200 & $01 / 06 / 2005$ & 11,600 & $01 / 06 / 2005$ & 8,280 \\
2006 & $03 / 13 / 2006$ & 12,000 & $03 / 12 / 2006$ & 5,890 & $03 / 13 / 2006$ & 6,380 \\
2007 & $03 / 24 / 2007$ & 20,300 & $03 / 02 / 2007$ & 8,990 & $03 / 02 / 2007$ & 6,950 \\
\hline
\end{tabular}

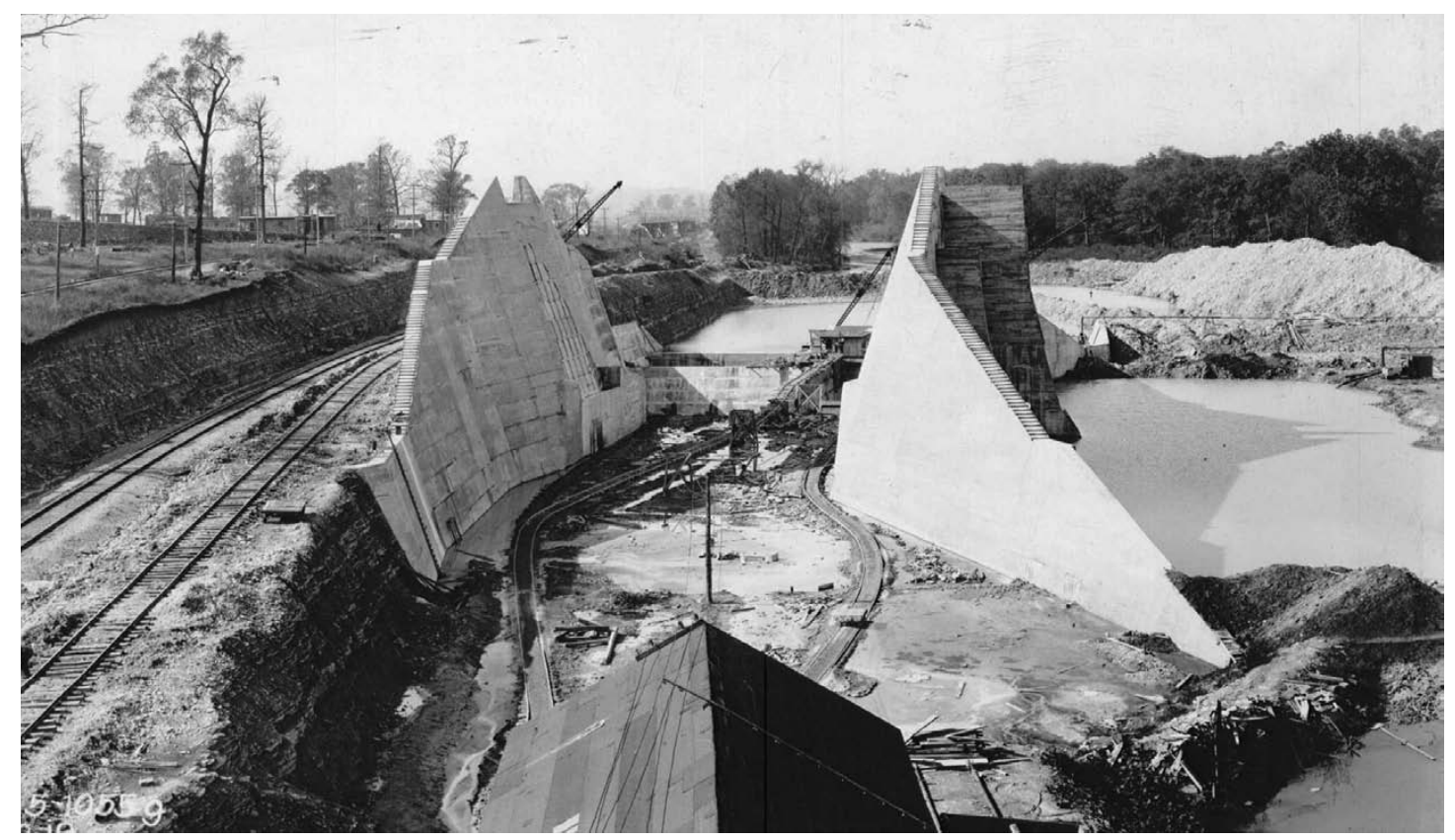

Construction of the outlet at Huffman Dam spillway. (Photo furnished by the Miami Conservancy District, copyright 1913-2009, all rights reserved; reproduced with permission.) 
Table 1-2. Annual peak dam-pool storages for the Taylorsville, Huffman, and Germantown Dams, water years 1922-2008.

[ns, no storage]

\begin{tabular}{|c|c|c|c|c|c|c|}
\hline \multirow[b]{2}{*}{ Water year } & \multicolumn{2}{|c|}{ Taylorsville Dam } & \multicolumn{2}{|c|}{ Huffman Dam } & \multicolumn{2}{|c|}{ Germantown Dam } \\
\hline & Date & $\begin{array}{c}\text { Storage } \\
\text { (acre-feet) }\end{array}$ & Date & $\begin{array}{c}\text { Storage } \\
\text { (acre-feet) }\end{array}$ & Date & $\begin{array}{c}\text { Storage } \\
\text { (acre-feet) }\end{array}$ \\
\hline 1922 & $04 / 15 / 1922$ & 3,240 & 04/15/1922 & 2,390 & $04 / 15 / 1922$ & 7,670 \\
\hline 1923 & & ns & & ns & 03/16/1923 & 534 \\
\hline 1924 & 06/08/1924 & 8,380 & 03/29/1924 & 4,920 & 03/29/1924 & 8,160 \\
\hline 1925 & & ns & & ns & 09/19/1925 & 558 \\
\hline 1926 & 04/09/1926 & 1,640 & 04/07/1926 & 79 & 09/02/1926 & 8,370 \\
\hline 1927 & 03/21/1927 & 9,200 & 01/20/1927 & 1,950 & 04/06/1927 & 2,260 \\
\hline 1928 & $12 / 14 / 1927$ & 2,180 & 12/01/1927 & 477 & $12 / 01 / 1927$ & 5,950 \\
\hline 1929 & 02/26/1929 & 10,700 & 02/26/1929 & 15,600 & $02 / 26 / 1929$ & 20,900 \\
\hline 1930 & 01/10/1930 & 6,790 & 01/10/1930 & 1,290 & 01/10/1930 & 8,800 \\
\hline 1931 & & ns & & ns & & ns \\
\hline 1932 & & ns & 01/18/1932 & 695 & 01/17/1932 & 1,790 \\
\hline 1933 & 05/14/1933 & 11,400 & 05/14/1933 & 3,770 & 12/31/1932 & 8,730 \\
\hline 1934 & & ns & & ns & $12 / 17 / 1933$ & 265 \\
\hline 1935 & 05/03/1935 & 687 & & ns & 05/03/1935 & 278 \\
\hline 1936 & 02/27/1936 & 2,480 & 02/27/1936 & 459 & $02 / 27 / 1936$ & 863 \\
\hline 1937 & 01/14/1937 & 11,100 & 01/21/1937 & 8,480 & 01/15/1937 & 17,800 \\
\hline 1938 & 04/09/1938 & 3,400 & 04/07/1938 & 949 & 03/14/1938 & 1,220 \\
\hline 1939 & 04/16/1939 & 1,310 & 04/15/1939 & 670 & 04/16/1939 & 3,910 \\
\hline 1940 & 04/21/1940 & 1,840 & 04/21/1940 & 459 & $04 / 20 / 1940$ & 2,540 \\
\hline 1941 & & ns & & ns & & ns \\
\hline 1942 & 04/11/1942 & 1,070 & & ns & 02/07/1942 & 894 \\
\hline 1943 & 03/20/1943 & 5,680 & 03/20/1943 & 3,300 & 03/20/1943 & 12,500 \\
\hline 1944 & $04 / 12 / 1944$ & 3,240 & 04/12/1944 & 949 & 04/11/1944 & 3,720 \\
\hline 1945 & 06/18/1945 & 2,610 & 03/07/1945 & 3,610 & 03/07/1945 & 6,430 \\
\hline 1946 & & ns & & ns & $02 / 14 / 1946$ & 1,680 \\
\hline 1947 & 06/03/1947 & 4,690 & 06/03/1947 & 4,000 & 06/02/1947 & 9,850 \\
\hline 1948 & $04 / 14 / 1948$ & 2,960 & 02/14/1948 & 6,340 & 02/13/1948 & 5,540 \\
\hline 1949 & 01/06/1949 & 3,800 & 01/06/1949 & 2,220 & 01/05/1949 & 15,200 \\
\hline 1950 & 01/16/1950 & 7,010 & 01/17/1950 & 1,900 & $01 / 16 / 1950$ & 8,230 \\
\hline 1951 & 02/21/1951 & 4,870 & 12/04/1950 & 2,220 & $02 / 21 / 1951$ & 9,540 \\
\hline 1952 & 01/27/1952 & 7,630 & 01/27/1952 & 8,220 & $01 / 27 / 1952$ & 19,700 \\
\hline 1953 & & ns & & ns & & ns \\
\hline 1954 & & ns & & ns & & ns \\
\hline 1955 & & ns & & ns & 03/21/1955 & 534 \\
\hline 1956 & 02/26/1956 & 1,840 & 11/17/1955 & 520 & 11/17/1955 & 6,190 \\
\hline 1957 & 06/29/1957 & 3,030 & 04/05/1957 & 3,020 & $04 / 04 / 1957$ & 8,580 \\
\hline 1958 & 06/14/1958 & 7,880 & 06/14/1958 & 3,610 & 08/02/1958 & 5,950 \\
\hline
\end{tabular}


Table 1-2. Annual peak dam-pool storages for the Taylorsville, Huffman, and Germantown Dams, water years 1922-2008.-Continued

\begin{tabular}{|c|c|c|c|c|c|c|}
\hline \multirow[b]{2}{*}{ Water year } & \multicolumn{2}{|c|}{ Taylorsville Dam } & \multicolumn{2}{|c|}{ Huffman Dam } & \multicolumn{2}{|c|}{ Germantown Dam } \\
\hline & Date & $\begin{array}{c}\text { Storage } \\
\text { (acre-feet) }\end{array}$ & Date & $\begin{array}{c}\text { Storage } \\
\text { (acre-feet) }\end{array}$ & Date & $\begin{array}{c}\text { Storage } \\
\text { (acre-feet) }\end{array}$ \\
\hline 1959 & 01/22/1959 & 20,300 & 01/22/1959 & 24,800 & 01/22/1959 & 33,400 \\
\hline 1960 & & ns & & ns & & ns \\
\hline 1961 & 04/26/1961 & 2,750 & 04/26/1961 & 545 & 04/25/1961 & 5,140 \\
\hline 1962 & 02/27/1962 & 1,270 & 02/27/1962 & 813 & 02/26/1962 & 3,200 \\
\hline 1963 & 03/05/1963 & 9,340 & 03/05/1963 & 13,400 & 03/05/1963 & 18,900 \\
\hline 1964 & 04/21/1964 & 5,780 & 03/10/1964 & 4,650 & 03/10/1964 & 11,300 \\
\hline 1965 & 04/26/1965 & 1,020 & 04/26/1965 & 203 & 04/25/1965 & 1,250 \\
\hline 1966 & 02/11/1966 & 209 & 02/11/1966 & 203 & 02/10/1966 & 787 \\
\hline 1967 & 05/08/1967 & 1,110 & & ns & 05/07/1967 & 2,880 \\
\hline 1968 & 01/31/1968 & 636 & 05/28/1968 & 74 & 05/24/1968 & 12,500 \\
\hline 1969 & 01/30/1969 & 1,360 & 08/10/1969 & 595 & 01/30/1969 & 3,810 \\
\hline 1970 & 04/03/1970 & 1,940 & 04/03/1970 & 1,800 & 04/02/1970 & 5,140 \\
\hline 1971 & 06/26/1971 & 1,310 & 06/26/1971 & 881 & 02/22/1971 & 2,800 \\
\hline 1972 & 04/08/1972 & 889 & & ns & 04/13/1972 & 680 \\
\hline 1973 & 11/15/1972 & 1,690 & 06/20/1973 & 387 & 11/14/1972 & 1,760 \\
\hline 1974 & 01/20/1974 & 2,060 & 04/02/1974 & 189 & 06/23/1974 & 2,430 \\
\hline 1975 & 02/24/1975 & 6,900 & 02/24/1975 & 3,220 & 02/24/1975 & 11,700 \\
\hline 1976 & 01/27/1976 & 754 & 01/26/1976 & 79 & 01/26/1976 & 1,650 \\
\hline 1977 & & ns & 04/03/1977 & 259 & 04/03/1977 & 3,330 \\
\hline 1978 & 03/15/1978 & 2,240 & 03/15/1978 & 495 & 03/15/1978 & 6,310 \\
\hline 1979 & 02/24/1979 & 2,360 & 09/15/1979 & 983 & 02/24/1979 & 4,340 \\
\hline 1980 & 06/03/1980 & 2,420 & 06/29/1980 & 2,050 & 11/26/1979 & 2,160 \\
\hline 1981 & 06/15/1981 & 2,180 & 06/06/1981 & 1,950 & 06/06/1981 & 570 \\
\hline 1982 & 02/18/1982 & 2,610 & 02/01/1982 & 2,390 & 02/01/1982 & 8,090 \\
\hline 1983 & 05/03/1983 & 721 & 05/02/1983 & 259 & 05/03/1983 & 4,100 \\
\hline 1984 & & ns & & ns & 04/05/1984 & 653 \\
\hline 1985 & 02/24/1985 & 2,890 & 02/24/1985 & 351 & 02/23/1985 & 1,900 \\
\hline 1986 & $12 / 12 / 1985$ & 1,740 & 03/13/1986 & 495 & 03/13/1986 & 2,290 \\
\hline 1987 & 10/05/1986 & 3,880 & 10/05/1986 & 570 & 10/02/1986 & 4,000 \\
\hline 1988 & & ns & & ns & 02/02/1988 & 1,540 \\
\hline 1989 & 05/27/1989 & 3,480 & 05/27/1989 & 1,080 & 05/26/1989 & 11,300 \\
\hline 1990 & 02/16/1990 & 2,750 & 07/13/1990 & 983 & 02/16/1990 & 4,600 \\
\hline 1991 & 12/31/1990 & 12,100 & 12/31/1990 & 2,760 & 12/31/1990 & 13,300 \\
\hline 1992 & 07/14/1992 & 1,890 & 07/18/1992 & 333 & 04/19/1992 & 976 \\
\hline 1993 & 07/03/1993 & 2,610 & 07/02/1993 & 387 & 04/16/1993 & 1,680 \\
\hline 1994 & 11/18/1993 & 2,180 & 01/28/1994 & 847 & 01/28/1994 & 3,160 \\
\hline 1995 & 08/09/1995 & 10,500 & 08/09/1995 & 369 & 05/18/1995 & 3,120 \\
\hline 1996 & 01/19/1996 & 3,480 & 04/30/1996 & 1,900 & 04/30/1996 & 12,800 \\
\hline 1997 & 06/02/1997 & 3,560 & 06/02/1997 & 915 & 06/02/1997 & 7,010 \\
\hline 1998 & 01/09/1998 & 1,590 & 05/08/1998 & 1,340 & 04/16/1998 & 2,620 \\
\hline
\end{tabular}


Table 1-2. Annual peak dam-pool storages for the Taylorsville, Huffman, and Germantown Dams, water years 1922-2008.-Continued

\begin{tabular}{lcc|c|c|c|c}
\hline \multirow{2}{*}{ Water year } & \multicolumn{2}{c|}{ Taylorsville Dam } & \multicolumn{2}{c|}{ Huffman Dam } & \multicolumn{2}{c}{ Germantown Dam } \\
\cline { 2 - 7 } & Date & $\begin{array}{c}\text { Storage } \\
\text { (acre-feet) }\end{array}$ & Date & $\begin{array}{c}\text { Storage } \\
\text { (acre-feet) }\end{array}$ & Date & $\begin{array}{c}\text { Storage } \\
\text { (acre-feet) }\end{array}$ \\
\hline 1999 & $01 / 23 / 1999$ & 2,960 & $01 / 22 / 1999$ & 231 & $01 / 23 / 1999$ & 6,130 \\
2000 & $04 / 08 / 2000$ & 1,440 & $04 / 08 / 2000$ & 1,250 & $04 / 08 / 2000$ & 4,550 \\
2001 & & $n$ ns & $07 / 29 / 2001$ & 217 & $04 / 11 / 2001$ & 1,290 \\
2002 & $12 / 18 / 2001$ & 2,480 & $12 / 18 / 2001$ & 813 & $12 / 18 / 2001$ & 7,270 \\
2003 & $07 / 10 / 2003$ & 8,930 & $09 / 02 / 2003$ & 423 & $07 / 07 / 2003$ & 1,840 \\
2004 & $01 / 05 / 2004$ & 5,270 & $01 / 05 / 2004$ & 2,960 & $01 / 05 / 2004$ & 14,800 \\
2005 & $01 / 06 / 2005$ & 16,000 & $01 / 06 / 2005$ & 3,380 & $01 / 06 / 2005$ & 19,300 \\
2006 & $03 / 13 / 2006$ & 1,740 & $03 / 13 / 2006$ & 387 & $03 / 12 / 2006$ & 4,450 \\
2007 & $03 / 24 / 2007$ & 6,330 & $03 / 03 / 2007$ & 1,650 & $03 / 02 / 2007$ & 8,020 \\
2008 & $03 / 20 / 2008$ & 5,680 & $03 / 20 / 2008$ & 2,220 & $03 / 20 / 2008$ & 12,400 \\
\hline
\end{tabular}

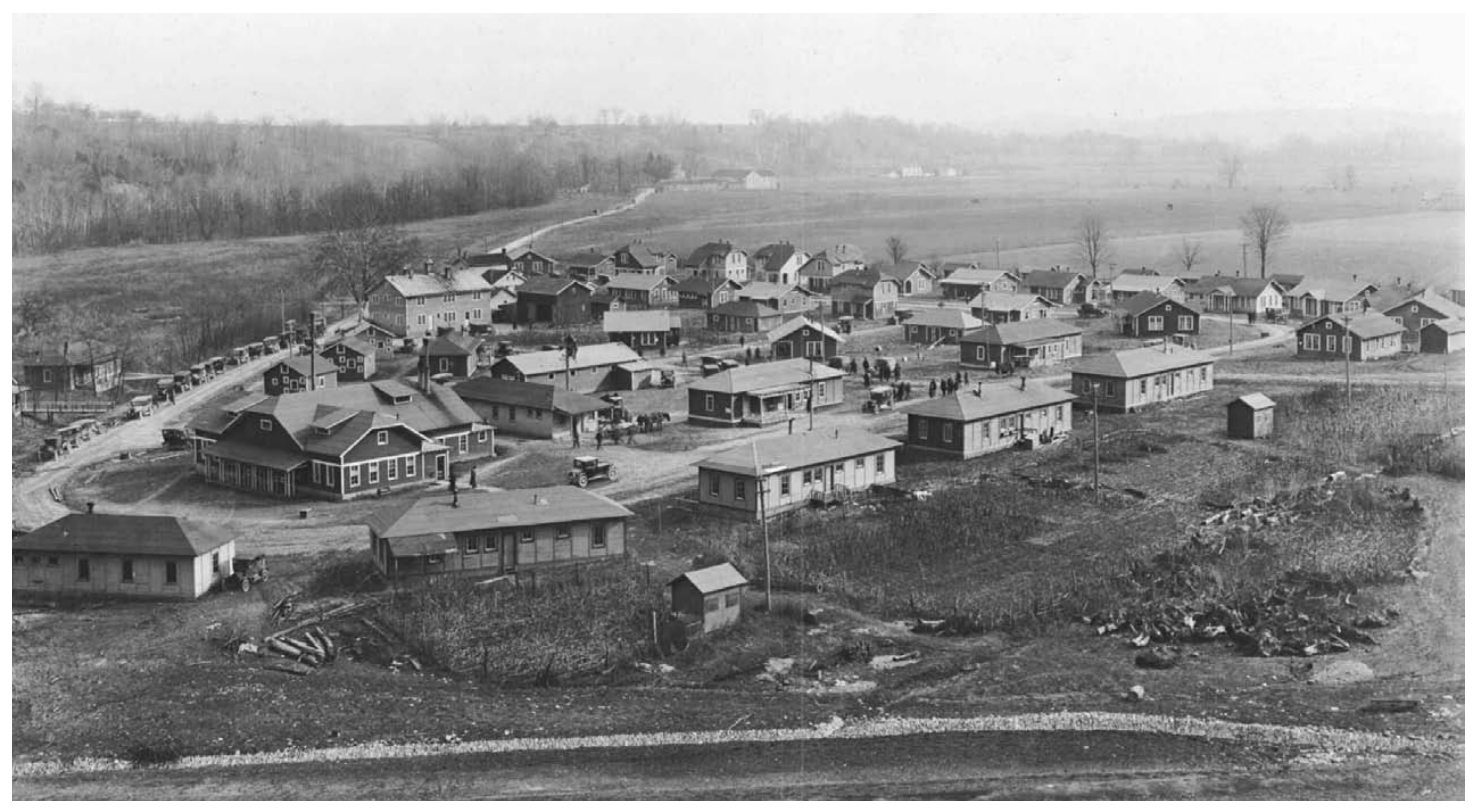

View of Germantown Dam construction-workers' camp in 1921. (Photo furnished by the Miami Conservancy District., copyright 1913-2009, all rights reserved; reproduced with permission.) 


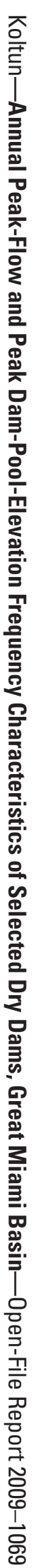

